\title{
Factors driving diversity and succession of diatom assemblages in a Neotropical rainforest stream
}

\author{
Jhon Charles Donato Rondón ${ }^{1, *}$ and Yaira Ayarith Abuhatab Aragón ${ }^{2}$ \\ ${ }^{1}$ Diatoms Laboratory, Biology Department, National University of Colombia, Cra 30 No. 45-03, Bogotá, Colombia \\ ${ }^{2}$ Limnology Laboratory, Technological University of Chocó, Choco, Colombia
}

Received: 29 January 2018; Accepted: 4 July 2018

\begin{abstract}
This study assessed short-term succession and related changes in diversity and succession of benthic diatom assemblages in a tropical rainforest stream in the biogeographic region of Chocó, Colombia. Diatom colonization in situ was studied over a 60-day period, in which we analyzed the number of valves and the taxonomic changes. The Shannon index ranged from 2.06 to 3.02 bits. A total of 127 species were identified and the most abundant were acidophilic species such as Eunotia intermedia, E. veneris, E. bilunaris var. mucophila, E. pirla and E. bilunaris. A Detrended Canonical Correspondence Analysis (DCCA) was used to explore the succession of diatom assemblages and its driving environmental factors. The DCCA explained $74.1 \%$ of the correlation between environmental variables and diatom species and $16.2 \%$ of the data variance. The species fell into four groups, the first group (Eunotia incisa, Frustulia saxonica, Fragilaria capucina var. acatu, among others) was related to lower nitrate concentrations, acidic $\mathrm{pH}$ and lower water temperature. The second group (Fragilaria capensis, Gomphonema olivaceum, Cymbella gracilis, among others) was associated to higher alkalinity and lower solar radiation availability. The third group (Nitzschia obtusa, N. amphibia, Naviculadicta vitabunda, Navicula cryptocephala, among others) was related to lower phosphate, higher nitrate concentrations, lower $\mathrm{pH}$, and higher temperatures. The fourth group (Eunotia soleirolli, Frustulia vulgaris and F. rhomboides) was associated with higher solar radiation and lower alkalinity. These results underscore the importance of diatom diversity in Neotropical streams and the relevance of small variations in environmental factors on the composition of reference assemblages of Neotropical fluvial systems.
\end{abstract}

Keywords: Diversity / discharge / artificial substrate / species richness / hydrological variables / Neotropical

\section{Introduction}

Diatoms are generally the most numerous and diverse primary producers in rivers and streams (Pan et al., 1999; Soininen, 2007) and yet, they are among the many groups of understudied organisms in Neotropical regions overall (Vyverman et al., 2007). Diatoms possess short generation times and life cycles, which makes them able to respond to environmental changes in a matter of days or weeks (Stevenson et al., 2010). Their autoecological requirements are strongly species-specific (Finlay et al., 2002; Tornés et al., 2007), and this has prompted their use as indicators of water chemistry (Pan et al., 2000) and other environmental conditions (light, temperature, and water velocity) that characterize the different

\footnotetext{
*Corresponding author: jcdonator@unal.edu.co
}

geographic regions (Martinez de Fabricius et al., 2003; Soininen, 2006; Heino et al., 2015).

Diatoms are generally cosmopolitan but these have a relevant fraction of endemic taxa to specific regions (Potapova and Charles, 2003; Cottenie, 2005), their assemblage structure is controlled by multiple factors prevailing at different temporal and spatial scales (Stevenson, 1997). The precise relationship between diatoms and the different environmental factors is complex and includes various factors such as light, substrate availability, nutrient concentration and hydrodynamics, as well as changes in space, time, dissolved organic carbon (DOC), $\mathrm{pH}$ and conductivity (Smucker and Vis, 2011). It has been observed, for example, that higher water velocity accounts for increased biomass and decreased speciesdiversity (Wellnitz and Rader, 2003) in some cases, while in others it yields lower biomass while maintaining speciesdiversity (Zapata and Donato, 2005). Physical disturbance plays a very important role in structuring diatom assemblages 
in fluvial systems (Boyero and De Lope, 2002; Stevenson et al., 2010).

The process of change in the species structure of an ecological community over time is a classic theme of ecology known as succession (Stevenson, 1990; Besemer et al., 2007). According to differences in local conditions, benthic algae assemblages follow different trajectories, so the succession in these communities cannot be explained by mechanistic models (Steinman, 1996). However, the factors, mechanisms and trajectories that drive succession in tropical rivers are poorly known.

The biogeographic region of Chocó extends from the north of Ecuador's Esmeraldas Province to the province of Darien in Southeastern Panama, and from the Pacific coast to the western range of Colombia's Andes (Rangel, 2004). The region's altitude varies from sea level to 2.000 m.a.s.l. The Chocó is one of the most complex hydrographic systems in northern South America, composed of diverse and heterogeneous habitats and numerous aquatic systems. Its habitat diversity and superhumid climate (its rainfall index is among the highest in the world) endow it with an unusually high degree of biodiversity, which is yet to be studied in-depth. The high levels of discharge, maintained by the unique rainfall regime of the region, can constrain the diversity and suppress the succession of diatom communities.

The present study sought to investigate the diatom diversity throughout succession in a Chocó stream. Assemblages can undergo succession as a response to both internal trade-offs of species within the community, biological influences, and environmental changes (Soininen et al., 2009). Temporal succession is a site-specific process (Steinman, 1996; Soininen, 2006) affecting the assemblage and involving modifications in species composition and dominance over time. We aimed to account for the smallscale environmental drivers affecting species richness and complexity throughout a 60 -day succession.

We analyzed the relevance of short-term changes in environmental conditions on the successional process driving the diatom community in an undisturbed stream in the Colombian province of Chocó. The frequent daily rains in this system cause high water velocities and water flow. We sought to determine how these discharge conditions affect the structure and diversity a diatom assembly, both directly and by affecting the associated environmental variables. We hypothesized that, in an oligotrophic environment subjected to daily rainfall, the composition of the diatom assembly would be related to variations in nutrient and light availability, overlapping those occurring in the discharge and water velocity.

\section{Methods}

\subsection{Study site}

La Francisca is a second-order tributary of the Atrato River ( $5^{\circ} 46^{\prime} 12^{\prime \prime} \mathrm{N} ; 76^{\circ} 45^{\prime} 04^{\prime \prime} \mathrm{W} ; 53 \mathrm{~m}$ a.s.l.) in the Colombian province of Chocó. It is a sand and gravel-bed stream consisting principally of riffles, surrounded by a welldeveloped riparian forest made up of Mora megistosperma, Pterocarpus officinalis, Raphia taedigera, and Montrichardia arborescens. The surrounding landscape is hilly, and its organic-clayey soil is poorly drained, acidic, and low in nitrogen, phosphorus, and potassium (IGAC, 1997). The local climate is tropical superhumid, with an annual average rainfall of $8.000 \mathrm{~mm}$. The rains are more intense from April to September and less intense from December to March. The average monthly temperature ranges from 25.7 to $27.9^{\circ} \mathrm{C}$ (Rangel, 2004).

\subsection{Sampling}

Daily sampling of biological and physical factors was carried out over a period of 60 days from December 2007 to January 2008. Solar radiation $\left(\mathrm{kw} \mathrm{h}^{-1}\right)$ and precipitation $(\mathrm{mm}$ $\mathrm{d}^{-1}$ ) were measured at the nearby Universidad Tecnológica del Chocó weather station. Water temperature $\left({ }^{\circ} \mathrm{C}\right)$ and conductivity $\left(\mu \mathrm{S} \mathrm{cm}^{-1}\right)$ were measured daily with Hach multiparameter equipment. Samples for alkalinity $\left(\mathrm{CaCO}_{3}\right.$ $\left.\mathrm{mg} \mathrm{l}^{-1}\right)$, $\mathrm{pH}\left(\mathrm{H}^{+}\right)$, phosphate $\left(\mathrm{mg} \mathrm{l}^{-1}\right)$, nitrate $\left(\mathrm{mg}^{-1}\right)$, and ammonia (mg $\mathrm{m}^{-1}$ ) were collected and measured following APHA, AWWA, \& WPCF methods (2005), these variables were taken between 9 am and 11 am every day to avoid daily variation. Although the $\mathrm{SiO}_{2}$ concentration was not estimated, the presence of volcanic rocks and andesitic-dacitic composition in the Atrato River basin (Galvis-V, 1996) suggests that there would be no significant limitations of Silice in the studied river. Discharge (expressed in $\mathrm{m}^{3} \mathrm{~s}^{-1}$ ) was estimated from measurements of the stream's width $(\mathrm{m})$, depth $(\mathrm{m})$, and water velocity $\left(\mathrm{m} \mathrm{s}^{-1}\right)$. The depth was measured at three points which were located at $25 \%, 50 \%$, and $75 \%$ of the channel width, and from these three measurements, the average water depth was calculated (Wetzel and Likens, 2000).

Sixty artificial substrates (clay tiles) were simultaneously submerged in the stream. One of them was collected from the stream every day over a 60 -day period. Once collected, diatom frustules were gently removed using a toothbrush and then cleaned from organic material using sulfuric acid, dichromate potassium and hydrogen peroxide. To count and identify diatoms, an Olympus Cx21 microscope was used. A $0.20 \mathrm{ml}$ portion of each sample was placed on a slide and observed at $400 \times$ and $1000 \times$ magnification. A total of 400 individual diatom valves were counted from each tile (APHA, AWWA and WPCF, 2005). Diatoms were identified using the classification system of Medlin and Kaczmarska (2004) and the monographs of Krammer and Lange-Bertalot (1986, 1991), Lange-Bertalot and Genkal (1999), Lange-Bertalot (1993, 2001), Krammer (1992, 2002), Metzeltin and Lange-Bertalot, (1998, 2007), and Rumrich et al. (2000). The relative frequency of each diatom species was computed according to the number of valves counted.

Hydrological, physical-chemical, and climatic data were normalized using natural logarithms. Spearman correlations were applied to define relations among the variables. Margalef's species richness index and the Shannon index $\left(\mathrm{H}^{\prime}\right.$, natural $\left.\log \right)$ were calculated according to the counts. The relationship between the relative abundance of the most common species (those with abundances $>10 \%$ ) and the environmental variables was evaluated by means of Detrended Canonical Correspondence Analysis (DCCA) (Kruskal, 1964). In this analysis, it was assumed that the species have a unimodal response to environmental variables, 

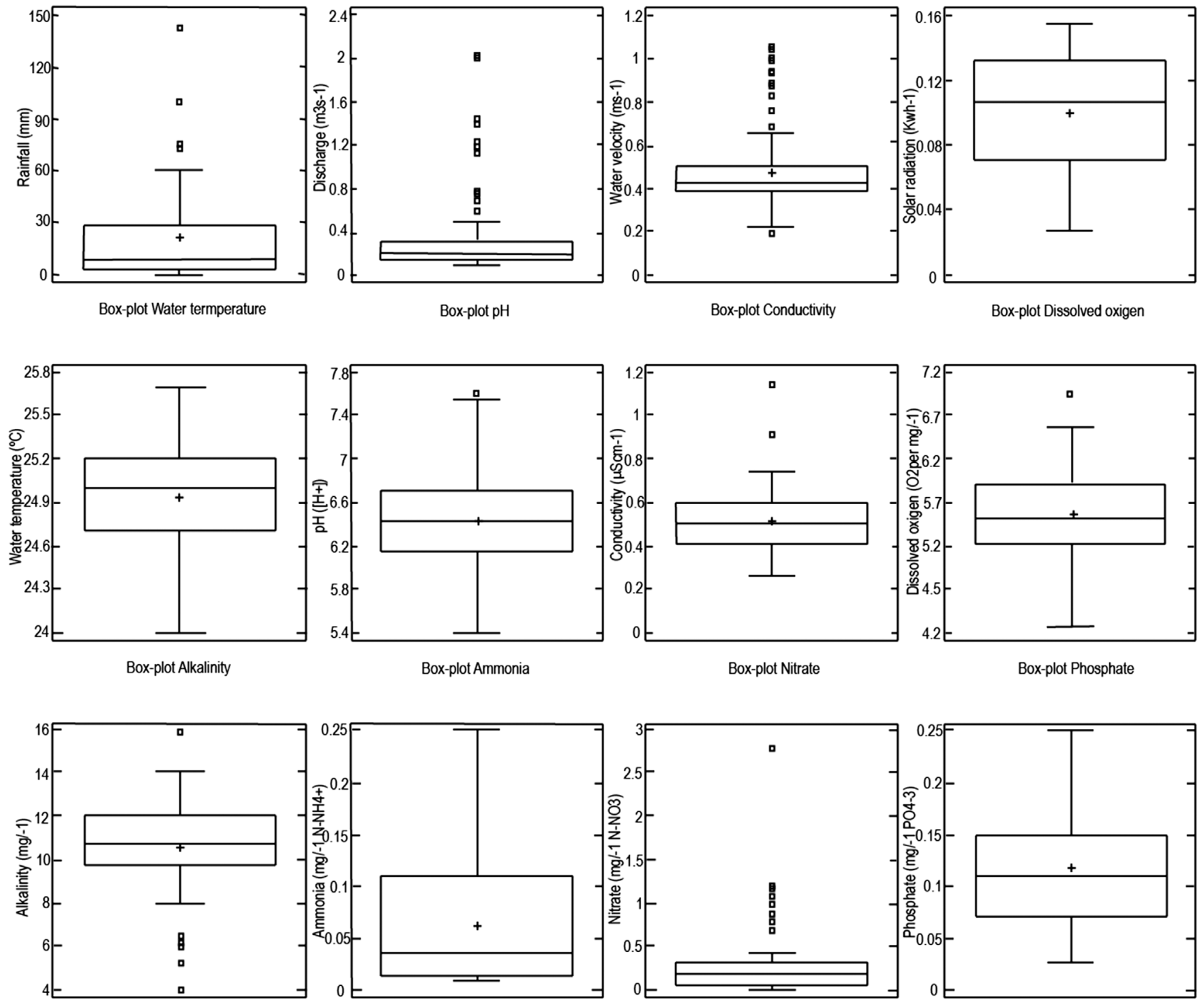

Fig. 1. Box-plot of environmental and hydrological variables daily recorded.

previously checked by Detrended Correspondence Analysis (ter Braak and Smilauer, 1998). All environmental variables had an inflation factor below 5\%. Model significance was tested through Monte Carlo simulation (9999 permutations). The coefficients of variation $(\mathrm{CV})$ were calculated to determine the strength of daily differences. To study how colonization changed over time, the day to day succession pattern of each diatom species was explored through non-parametric Spearman's correlation (McCormick and Stevenson 1991). Correlation significance $(\mathrm{p} \leq 0.05)$ and sign were used to classify species as early successional (significant negative correlation), late successional (significant positive correlation), or indifferent or permanent (non-significant correlation).

The DCCA was performed with the statistical program CANOCO, version 4.5. The Exploratory and Pearson's correlation Analyses were carried out with Statgraphics Plus, version 5.1. Margalef's species richness and Shannon index were determined with PAST, version 1.34.

\section{Results}

\subsection{Environmental variables}

The total rainfall for all 60 days of the study was $2.000 \mathrm{~mm}$. The peak daily precipitation was $142.8 \mathrm{~mm} \mathrm{~d}^{-1}$, and the average daily rainfall was $20.2 \mathrm{~mm} \mathrm{~d}^{-1}$. Discharge averaged $2.02 \pm 0.2 \mathrm{~m}^{3} \mathrm{~s}^{-1}$ and fluctuated greatly (coefficient of variation $=115.1 \%$ ). Spearman's correlation indicated that discharge variability was positively correlated $(\mathrm{N}=60$, $\mathrm{r}=0.04, \mathrm{p}=0.04$ ) with the daily rainfall (Fig. 2). Solar radiation ranged from 0.028 to $0.155 \mathrm{kw} \mathrm{h}^{-1}$ and averaged $0.1001 \mathrm{kw} \mathrm{h}^{-1}$. Water temperature was high $\left(24.9 \pm 0.37^{\circ} \mathrm{C}\right)$ 
Table 1. Diatom and different stages during process succession of the stream La Francisca.

\begin{tabular}{lll}
\hline Early species (negative & Later species (positive & Permanent species (non-significant \\
Spearman's correlation) & Spearman's correlation) & Spearman's correlation) \\
\hline Pinnularia similis & Gomphonema angustum & Naviculadicta difficillima \\
Eunotia bilunaris var. bilunaris & Cymbella hillardii & Tabellaria fenestrata \\
Frustulia rhomboides var. viridula & Encyonema silesiacum & Encyonema neogracile \\
& Surirella sp $_{2}$ & Pinnularia appendiculata \\
& Gomphonema olivaceum & Navicula erifuga \\
& Eunotia incisa & Eunotia intermedia \\
& Encyonema neomesianum & Eunotia bilunaris \\
& Eunotia bilunaris var. mucophila & Navicula gregaria \\
Encyonema elginense & Navicula sp \\
Encyonema neomuelleri & Tabularia fasciculata \\
Eunotia pirla & Eunotia bilunaris \\
& & Eunotia glacialis \\
& & Naviculadicta vitabunda \\
& & Eolimna subminuscula \\
& & Navicula cryptocephala \\
\end{tabular}

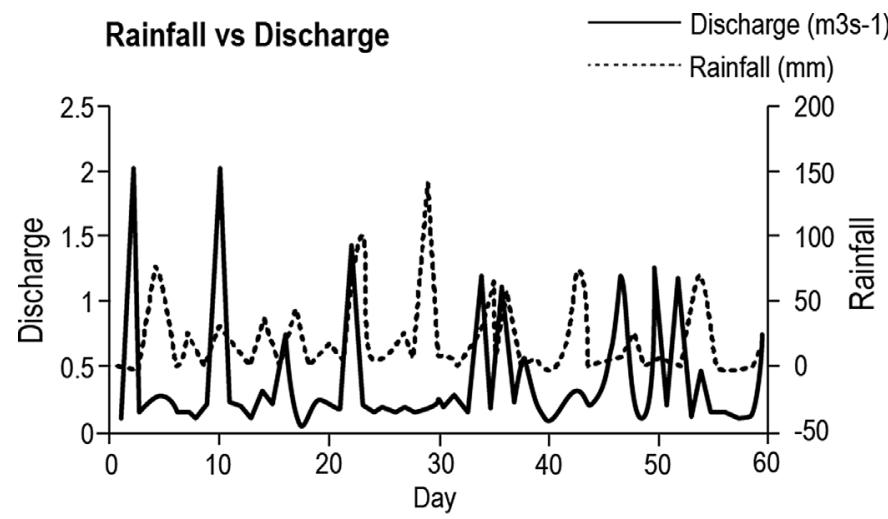

Fig. 2. Variation of rainfall and discharge during the sampling period in the stream La Francisca.

and remained almost constant $(\mathrm{CV}=1.46 \%)$, as is normal in streams in the Chocó region. The water had a moderately acid $\mathrm{pH} \quad(\mathrm{pH}=6.43 \pm 0.40), \quad$ low conductivity $\quad(10.41 \pm 3.0$ $\left.\mu \mathrm{S} \mathrm{cm}^{-1}\right)$, and low alkalinity $\left(10.6 \pm 2.4 \mathrm{CaCO}_{3} \mathrm{mg} \mathrm{l}^{-1}\right)$. Nutrient concentrations varied greatly from 1 day to the next

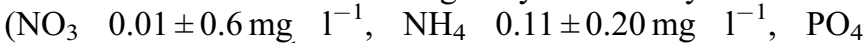
$\left.0.121 \pm 0.005 \mathrm{mg}^{-1}\right)$. The phosphorus estimate shows the availability of this nutrient in the Chocó basin and therefore to the same activity of the diatoms. The physical and chemical properties of the stream water are presented in Figure 1.

Spearman's correlation indicated that discharge variability was positively correlated $(\mathrm{N}=60, \mathrm{r}=0.04, \mathrm{p}=0.04)$ with the daily rainfall (Fig. 2). Solar radiation ranged from 0.028 to $0.155 \mathrm{kw} \mathrm{h}^{-1}$ and averaged $0.1001 \mathrm{kw} \mathrm{h}^{-1}$.

\subsection{Diatom assemblages composition}

A total of 127 diatom species were identified, most of them belonging to the classes Bacillariophyceae (98.8\%) and
Coscinodiscophyceae (1.2\%). The total number of frustules varied little (378-400) from sample to sample $(\mathrm{CV}=17.7 \%)$. Early, later and permanent successional species are listed in Table 1. The most frequent genus was Eunotia, including species such as E. intermedia (Krasske ex Hustedt) Nörpel et Lange-Bertalot $(27.55 \%)$, E. veneris (Kützing) De Toni (17.15\%), E. bilunaris var. mucophila Lange-Bertalot, Norpel et Alles (7.95\%), E. pirla Carter and Flower (6.04\%), and E. bilunaris (Ehrenberg) Schaarschmidt (1.08\%). Frequently counted species of other genera were Frustulia saxonica Rabenhorst (4.32\%), Navicula difficillima (3.58\%), Encyonema silesiacum (Bleisch) Mann (3.39\%), Encyonema elginense (Krammer) Mann (2.53\%), Navicula radiosa Kützing (2.33\%), Frustulia crassinervia (Brébisson) LangeBertalot et Krammer (2.18\%), Navicula cryptocephala Kützing (1.90\%), Encyonema minutum (Hilse in Rabenhorst) Mann (1.82\%), Frustulia rhomboides krammeri LangeBertalot et Metzeltin (1.61\%), and Naviculadicta vitabunda (Hustedt) Lange-Bertalot (1.31\%).

Ranging from 20 to 53 species a day, the Margalef's species richness index had low variability $(\mathrm{CV}=25.7 \%)$ and was significantly correlated to discharge (Pearson correlation, $\mathrm{n}=60$, $\mathrm{r}=0.043 ; \mathrm{p}=0.04)$. The Shannon index, ranging from 2.06 to 3.02 bits, was relatively high and remained relatively stable from day to day $(\mathrm{CV}=8.22 \%)$. Changes in relative abundance, species richness, Shannon index, and environmental variables and their relation to discharge are presented in Figure 3.

\subsection{Relation of environmental variables to species}

The DCCA (Fig. 4) explained $74.1 \%$ of the correlation between the environmental variables and the diatom species, as well as $16.2 \%$ of the data variance. The first axis is related to trophic conditions: phosphate and $\mathrm{pH}$ show the highest correlation to this axis. The second axis represents the mineral-water, as it is strongly correlated to alkalinity and water temperature. 

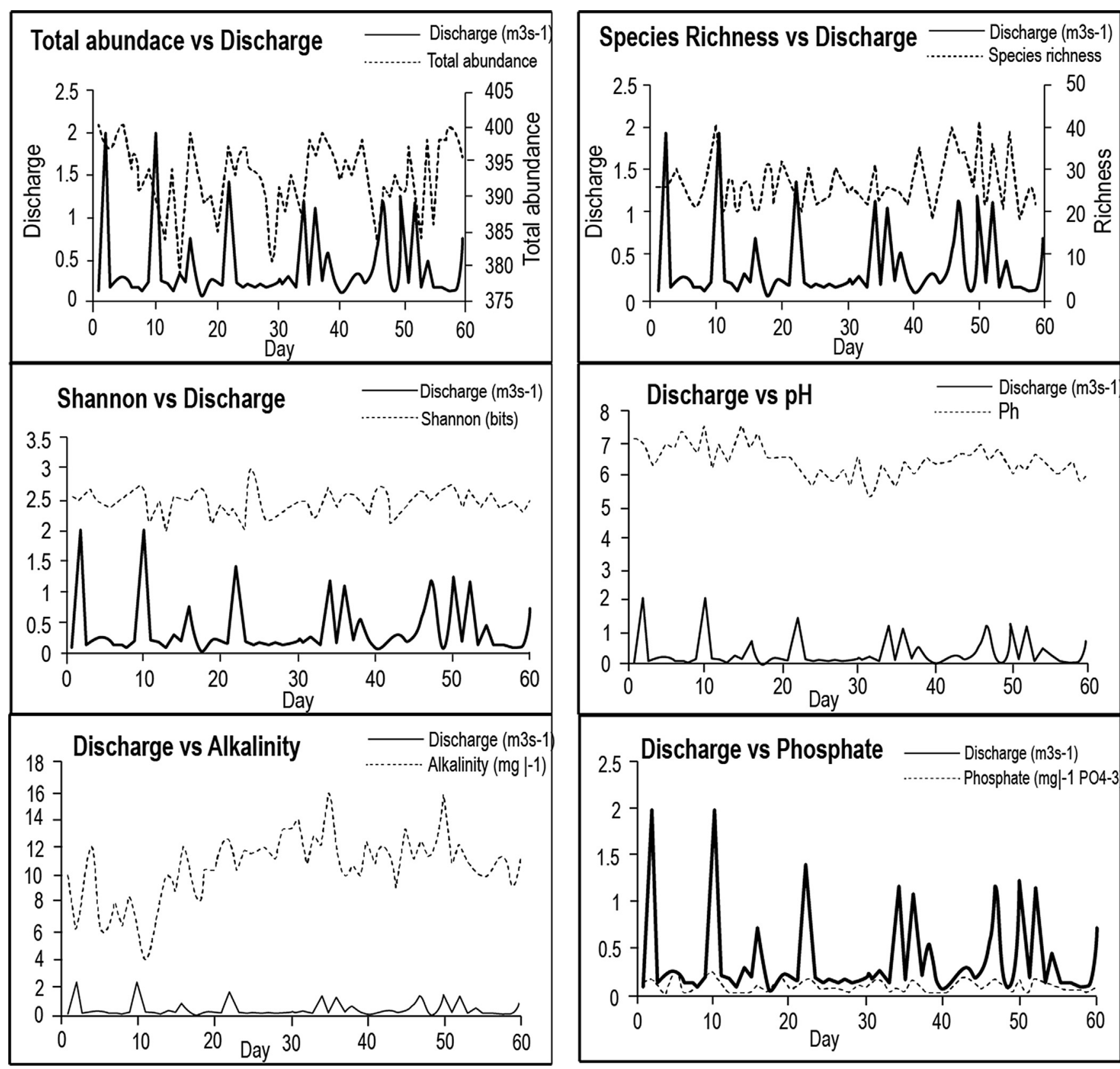

Fig. 3. Daily changes of discharge $\left(\mathrm{m}^{3} \mathrm{~s}^{-1}\right)$ and relative abundance, species richness and Shannon index (Bits) during the sampling period in the stream La Francisca.

The DCCA revealed that the species clustered around four main groups. The first group consisted of Eunotia incisa (Smith ex Gregory), Frustulia saxonica (Rabenhorst), Fragilaria capucina var. acatu (Ehrenberg), Encyonema elginense (Krammer), Craticula halophila (Grunow) Mann, Adlafia bryophila (Petersen) Lange-Bertalot, Neidium affine (Ehrenberg) Pfitzer, Surirella $\mathrm{sp}_{1}$, and Surirella $\mathrm{sp}_{2}$, among others. These species were related to higher phosphate, higher $\mathrm{pH}$, and lower water temperature. The second group contained species, such as Fragilaria capensis (Grunow), Gomphonema olivaceum (Hornemann) Brébisson, Eunotia incisa var. incisa (Gregory), Cymbella gracilis (Rabenhorst) Cleve, Cymbella muelleri (Hustedt), and Pinnularia appendiculata (C. Agardh), associated with higher alkalinity and lower radiation availability. The third group was made up of species such as Nitzschia obtusa (Smith), N. amphibia (Grunow), Naviculadicta vitabunda (Hustedt) Lange-Bertalot, Navicula cryptocephala (Kützing), Navicula $\mathrm{sp}_{2}$, Eunotia glacialis (F.Meister), E. paludosa var. paludosa (Grunow), E. subarcuatoides (Alles) Norpel et Lange-Bertalot, and Cymbella hillardii (Manguin). These species were related to lower phosphate, lower $\mathrm{pH}$, and higher water temperatures. The last group encompassed Eunotia soleirolli (Kützing) Rabenhorst, Frustulia vulgaris (Thwaites) De Toni, and Frustulia rhomboides (Ehrenberg) De Toni, species associated with higher solar radiation availability and lower alkalinity. 

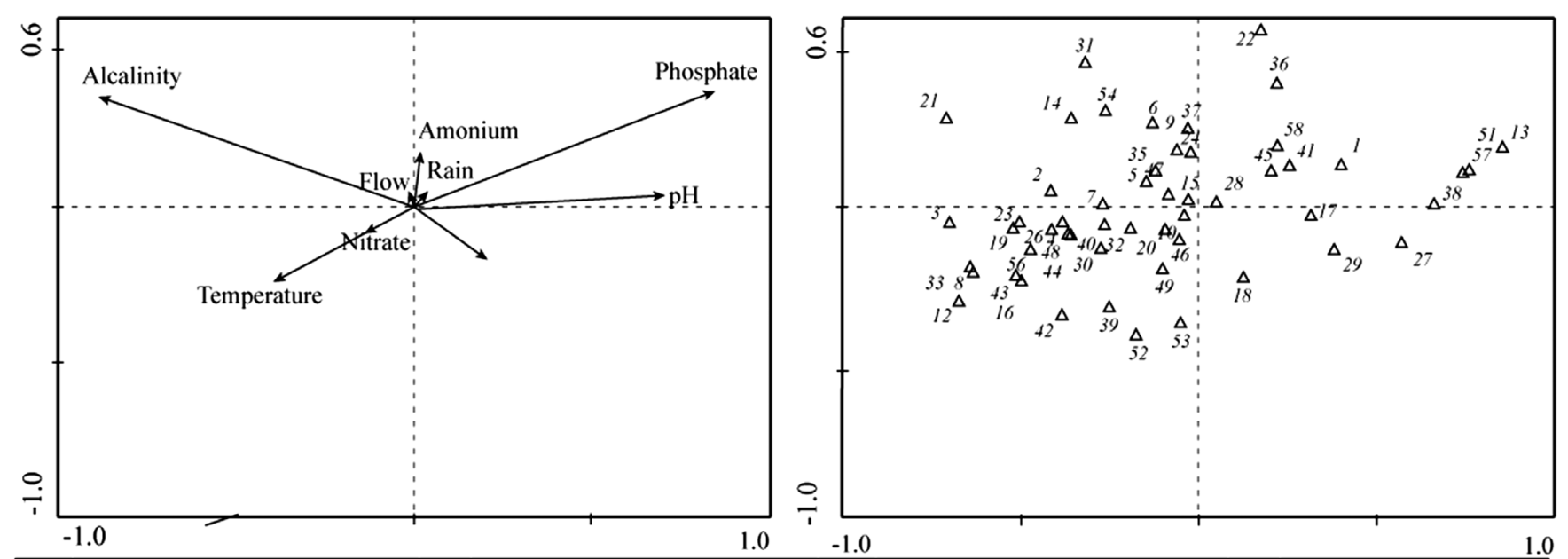

\begin{tabular}{|c|c|c|c|c|c|c|c|}
\hline $1-$ & Encyonema elginense & 16- & Eunotia paludosa var: paludosa & $31-$ & Gomphonema olivaceum & $46-$ & Navicula sp. \\
\hline $2-$ & Cymbella gracilis & $17-$ & Eunotia pirla & $32-$ & Navicula maceria & $47-$ & Navicula radiosa \\
\hline 3- & Cymbella hillardii & $18-$ & Eunotia soleirolli & $33-$ & Naviculadicta vitabunda & 48 - & Navicula radiosafallax \\
\hline 4- & Encyonemaneo neomesianum & 19- & Eunotia subarcutoides & 34- & Navicula angusta & $49-$ & Navicula riparia \\
\hline 5- & Encyonema minutum & $20-$ & Eunotia veneris & $35-$ & Navicula atomus & $50-$ & Navicula seminulum \\
\hline 6- & Cymbella muelleri & $21-$ & Fragilaria capensis & $36-$ & Adlafia bryophila & $51-$ & Neidium affine \\
\hline $7-$ & Encyonema silesiacum & $22-$ & Fragilaria capucina var: acuta & $37-$ & Navicula cari & $52-$ & Nitzschia amphibia \\
\hline $8-$ & Eunotia bilunaris & $23-$ & Tabularia fasciculata & $38-$ & Navicula sp. & 53- & Nitzschia obtusa \\
\hline 9- & Eunotia bilunaris var: bilunaris & 24- & $\begin{array}{r}\text { Fragilaria fonticola } \\
\end{array}$ & $39-$ & Navicula crucicula var crucicula & 54- & Pinnularia appendiculata \\
\hline $10-$ & Eunotia bilunaris var mucophila & $25-$ & Frustulia romboides var: viridula & 40- & Navicula cryptocephala & $55-$ & Pinnularia similis \\
\hline 11- & Eunotia exigua & 26- & Frustulia crassinervia & 41- & Navicula declivis & $56-$ & Pinnularia viridis \\
\hline $12-$ & Eunotia glacialis & $27-$ & Frustulia rhomboides & 42- & Naviculadicta difficillima & $57-$ & Surirella spl. \\
\hline 13- & Eunotia incisa & $28-$ & Frustulia saxonica & 43- & Navicula erifuga & 58- & Surirella sp2. \\
\hline 14- & Eunotia incisa var incisa & $29-$ & Frustulia vulgaris & 44- & Navicula gregaria & $59-$ & Tabellaria fenestrata \\
\hline $15-$ & Eunotia intermedia & $30-$ & Gomphonema angustum & 45- & Craticula halophila & & \\
\hline & & & & & & & \\
\hline
\end{tabular}

Fig. 4. Canonical correspondence analysis of the 59 species most representative and environmental and hydrological variables of the stream La Francisca.

\section{Discussion}

Daily variation in solar radiation and high rainfall are distinct features of the Chocó region, resulting in one of the rainiest environments of South America (Rangel, 2004). We observed small variation in water temperature, conductivity, and $\mathrm{pH}$, but relatively high variability in nutrient concentrations, which are probably linked to biological activity and soil leaching (Feller and Beare, 1997). Similar to nutrient concentrations, amount of rainfall exhibited a great variability on a daily basis and was greater than in other tropical streams (Allan and Castillo, 2007). We observed that rainfall and discharge were positively correlated, and the region's large, highly variable rainfall regime and associated changes in discharge should have played an important role in the physicalchemical and biological water dynamics of La Francisca. The rapid alternation of rainy and non-rainy days not only affects discharge, but also could explain the daily fluctuations in nutrient availability, mineralization, and solar radiation.

\subsection{Dominant species and species diversity}

The daily flow variation, as well as the varying nutrient and ionic composition, influenced stream diversity and diatom colonization. Diatom communities were frequently scoured and responded to small changes in nutrients. Of all species encountered during the successional process, $57.9 \%$ were acidophilic, followed by cosmopolitan species (34.9\%), and circumneutral $(7.14 \%)$. The relevance of Eunotia species among the other taxa in the diatom assemblage is related to the low mineral environments (Andren and Jarlman 2008; Bicca et al., 2011).

La Francisca's fluvial ecosystem hosted a high-diversity diatom assemblage (Tab. 2), similar to others observed in other Central and South American ecosystems such as Mexico's Magdalena River (Bojorge and Cantoral, 2007) and the Piedra Blanca River in Córdoba, Argentina (Luján et al., 2005).

\subsection{Benthic diatom colonization and development}

The algal benthic communities dominated by diatoms are relatively susceptible to disturbances by the river current (Peterson, 1996). Several studies have shown that pioneer colonizing algae are large, elongated or with colonial growth forms, which are followed by diatoms of small sizes with dominant filamentous forms at the end of the series. In general terms, our results correspond to the previously reported, seeing that in the initial stage there are genera such as Pinnularia and Frustulia and in the final stage Navicula spp, Eunotia spp, and Tabellaria spp. 
Table 2. Comparison of diatom diversity in other tropical systems fluvial.

\begin{tabular}{lll}
\hline Regions & Fluvial systems & Shannon index \\
\hline \multirow{4}{*}{ Central and South American } & River Magdalena (Mexico D. F) (Bojorge \& Cantoral, 2007) & 3.3 \\
& River Piedra Blanca (Cordoba - Argentina) (Luján et al 2005) & 3.5 \\
& River La Mina (Puerto Rico) (Gualtero, 2007) & 2.9 \\
& River Sonadora (Puerto Rico) (Gualtero, 2007) & 2 \\
& Streams Tota (Iza - Boyacá) (Rivera \& Donato 2008) & 1.9 \\
Colombia & River Chocontá (Bogotá) (Díaz \& Rivera, 2004) & 2.7 \\
& River Siecha (Bogotá) (Díaz \& Rivera, 2004) & 1.3 \\
Chocó & Stream Las Delicias (Bogotá) (Díaz \& Rivera, 2004) & 2 \\
& Stream La Hoya (Bogotá) (Díaz \& Rivera, 2004) & 3.0 \\
\hline
\end{tabular}

Benthic diatom colonization and development on tile surfaces is the direct consequence of immigration, reproduction, disturbance, death, grazing, and emigration. In our study, species richness peaked after 16 days and seemed to stabilize thereafter. There was significant arrival of new colonizers within the first 5 days, e.g., the Pinnularia similis, Eunotia bilunaris var. bilunaris, and Frustulia rhomboides var. viridula. Pioneer colonists, such as Fragilaria and Pinnularia, were mostly relatively large and had an advantage during immigration in that they can settle rapidly to the substrate (Stevenson, 1997). Gomphonema spp, Eunotia spp, Encyonema spp, Navicula spp, and Cymbella spp became dominant as time progressed. These are considered as intermediate to late colonizers, as most of these genera have low immigration ability but their small size makes them fast reproducers, and they are probably better competitors in disturbed environments (Lane et al., 2003; Soininen et al., 2004). Discharge created unsteady conditions that tend to restrict the presence of algal species to those capable of resisting hydrological fluctuation (Rivera and Donato 2008). Discharge contributed to the diversity and succession of the diatom assemblage and accounted for the changes in diversity on a daily scale, producing a "saw effect". This pattern was therefore associated with water flow, which has an abrasive or drag effect on diatoms, restarting colonization processes on substrate. This definitively indicated, as predicated by the study's original hypothesis, that discharge was a significant factor in determining the composition of La Francisca's diatom-assemblage. However, the day to day variation in the assemblage composition was also related to the minor variations in nutrient availability driven by water flow.

\section{Conclusions}

In light of the foregoing, it was concluded that diatom diversity in the La Francisca stream is relatively high and that acidophilic species are the most abundant. Moreover, the highly variable rainfall regime and associated changes in water flow must have played an important role in its physicalchemical and biological water dynamics. It was further postulated that, in so far as La Francisca is representative of streams in Chocó, diatom diversity there must be relatively high and acidophilic species must be the most abundant in the region's streams. These results underscore the importance of diatom diversity in neotropical streams, and this data is essential for a critical approach to the composition of reference assemblages and sites of neotropical fluvial systems.

Acknowledgements. The authors wish to thank Colciencias which provided financial support for conducting of the research, Universidad Tecnológica del Chocó and Universidad Nacional de Colombia for their support of field and laboratory activities and to biologist Viviana Infante for support. The authors wish to thank Dr. Sergi Sabater and Dr. Juan David Gonzalez for revising the manuscript, finally to Dr. Allan Wood for the grammatical comments on the manuscript.

\section{References}

Allan JD, Castillo MM. 2007. Stream Ecology: Structure and Function of Running Waters. Dordrecht: Springer.

Andren C, Jarlman A. 2008. Benthic diatoms as indicators of acidity in streams. Fundam Appl Limnol 173: 237-253.

APHA, AWWA and WPCF. 2005. Standard Methods for the Examination of Water and Wastewater. 21st edn, Washington DC: American Public Health Association.

Besemer K, Singer G, Limberger R, Chlup A-K, Hochedlinger G, Hödl I, Baranyi C, Battin TJ. 2007. Biophysical controls on community succession in stream biofilms. Appl Environ Microbiol 7315: 4966-4974.

Bicca A, Carvalho L, Bahi C. 2011. Eunotiaceae (Eunotiales, Bacillariophyta) em ambientes lacustres na Planície Costeira do Sul do Brasil. Rev Brasil Bot 34: 1-19.

Bojorge-Garcia M, Cantoral-Uriza EA. 2007. Estructura comunitaria de diatomeas asociadas a talos de Prasiola mexicana (Chlorophyta) en el rio Magdalena D. F. Hidrobiológica 17: 11-24.

Boyero L, De Lope JL. 2002. Short-term recolonization of stones in a tropical island stream. Mar Freshwater Res 53: 993-998.

Cottenie K. 2005. Integrating environmental and spatial processes in ecological community dynamics. Ecol Lett. 8: 1175-1182.

Díaz CA, Rivera C. 2004. Diatomeas de pequeños ríos andinos y su utilización como indicadoras de condiciones ambientales. Caldasia 26: 381-394.

Feller C, Beare MH. 1997. Physical control of soil organic matter dynamics in the tropics. Geoderma 79: 69-116. 
Finlay B, Monaghan E, Maberly S. 2002. Hypothesis: the rate and scale of dispersal of freshwater diatom species is a function of their global abundance. Protist 153: 261-273.

Galvis-V J. 1996. El origen del platino en el Chocó. Revista Geología Colombiana (Bogotá) 20: 107-112.

Gualtero D. 2007. Composición y abundancia de las algas bénticas de cinco sistemas lóticos de Puerto Rico. University of Puerto Rico, Mayaguez, Puerto Rico.

Heino J, Melo A, Siqueira T. 2015. Metacommunity organization, spatial extent and dispersal in aquatic systems: patterns, processes and prospects. Freshwater Biol 60: 845-869.

IGAC. 1997. Zonas de vida o Formaciones Vegetales de Colombia. Instituto Geografico Agustin Codazzi, Bogotá.

Krammer K. 1992. Die Gattun Pinnularia in Bayern. Hoppea Bd. 52, Resenburg, p. 308.

Krammer K. 2002. Cymbella. In: Lange-Bertalot H, ed. Diatoms of Europe, diatoms of the European inland waters and comparable habitats, Vol. 3 pp. 1-584, incl. 194 pls. Ruggell: A.R.G. Gantner Verlag K.G.

Krammer K, Lange-Bertalot H. 1986. Bacillariophyceae, 1. Teil: Naviculaceae. VEB. Gustav Fisher Verlag, Jena, p. 576.

Krammer K, Lange-Bertalot H. 1991. Bacillariphyceae, 3. Teil: Centrales, Fragilariaceae, Eunotiaceae. VEB. Gustav Fisher Verlag, Jena, p. 576.

Kruskal JB. 1964. Multidimensional scaling by optimizing goodness of fit to a nonmetric hypothesis. Psychometrika 29: 1-27.

Lane CM, Taffs KH, Corfield JL. 2003. A comparison of diatom community structure on natural and artificial substrata. Hydrobiologia 493: 65-79.

Lange-Bertalot H. 1993. 85 Neueu taxa. Bibliotheca Diatomologica Band 27.

Lange-Bertalot H. 2001. Diatoms of Europe. Vol. 2, Germany: E.R.G. Gantner Verlag KG.

Lange-Bertalot H, Genkal S. 1999. Diatoms from Siberia I. A.R.G. Gantner Verlag KG, p. 295.

Luján A, Luque E, Boccolini M. 2005. Diatomeas planctónicas de cursos de agua. Cuenca del Río Piedra Blanca (Córdoba, Argentina). Bol Soc Argent Bot 40: 3-4.

Martinez de Fabricius AL, Maidana N, Gómez N, Sabater S. 2003. Distribution patterns of benthic diatoms in a Pampean river exposed to seasonal floods: the Cuarto River (Argentina). Biodivers Conserv 12: 2443-2454.

McCormick PV, Stevenson RJ. 1991. Mechanisms of benthic algal succession in different flow environments. Ecology 72: 1835-1848.

Medlin LK, Kaczmarska I. 2004. Evolution of the diatoms: V. Morphological and cytological support for the major clades and a taxonomic revision. Phycologia 43: 245-270.

Metzeltin D, Lange-Bertalot H. 1998. Tropische Diatomeen in Sudamerika I. 700 überwiegend Wenig bekannte oder neue Taxa repräsentativ als Elemente der neotropischen Flora. Iconogr Diatomol 5: 1-695.

Metzeltin D, Lange-Bertalot H. 2007. Tropical diatoms of South America II. Special remark on biogeographic disjunction. Iconogr Diatomol 18: 1-876.

Pan YD, Stevenson RJ, Hill BH, Kaufmann PR, Herlihy AT. 1999. Spatial patterns and ecological determinants of benthic algal assemblages in Mid-Atlantic streams, USA. J Phycol 35: 460-468.

Pan YD, Stevenson RJ, Hill BH, Herlihy AT. 2000. Ecoregions and benthic diatom assemblages in Mid-Atlantic Highlands streams, USA. J North Am Benthol Soc 19: 518-540.

Peterson CG. 1996. Response of benthic algal communities to natural physical disturbance. In: Stevenson RJ, Bothwell ML, Lowe RL, eds.
Algal Ecology. Freshwater Benthic Ecosystems. San Diego, California: Academic Press Inc., pp. 375-403.

Potapova MG, Charles DF. 2003. Distribution of benthic diatoms in U.S. rivers in relation to conductivity and ionic composition. Freshw Biol 48: 1311-1328.

Rangel JO, 2004. El Chocó Biogeográfico. Ambiente físico. In: Rangel JO, ed. Colombia Diversidad Biótica IV. El Chocó Biogeográfico/Costa Pacífica. 1 ed. Universidad Nacional de Colombia, pp. 1-21.

Rivera C, Donato J. 2008. Influencia de las variaciones hidrológicas y químicas sobre la diversidad de diatomeas bénticas. In: Donato J, ed. Ecología de un río de montaña de los andes colombianos (Río Tota), Universidad Nacional de Colombia, pp. 83-102.

Rumrich U, Lange-Bertalot H, Rumrich H. 2000. Diatomeen der Andes von Venezuela bis Patagonien (Feuerland). Iconogr Diatomol 9: 1-649.

Smucker NJ, Vis ML. 2011. Spatial factors contribute to benthic diatom structure in streams across spatial scales: considerations for biomonitoring. Ecol Indic 11: 1191-203.

Soininen J. 2006. Local and regional coexistence of diatoms on the mechanisms promoting high local diatom species richness. Diatom Res 21: 217-223.

Soininen J. 2007. Environmental and spatial control of freshwater diatoms - a review. Diatom Res 22: 473-490.

Soininen J, Paavola R, Muotka T. 2004. Benthic diatom communities in boreal streams: community structure in relation to environmental and spatial gradients. Ecography 27: 330-342.

Soininen J, Heino J, Kokocinski M, Muotka T. 2009. Local-regional diversity relationship varies with spatial scale in lotic diatoms. $J$ Biogeogr 36: 720-727.

Steinman. 1996. Effects of grazers on freshwater benthic algae. In: Stevenson RJ, Bothwell ML, Lowe RL, eds. Algal Ecology. Freshwater Benthic Ecosystems. San Diego, California: Academic Press Inc., pp. 341-373.

Stevenson RJ. 1990. Benthic algal community dynamics in a stream during and after a spate. J North Am Benthol Soc 9: 277-288.

Stevenson RJ. 1996. The stimulation and drag of current. In: Stevenson RJ, Bothwell ML, Lowe RL, eds. Algal Ecology. Freshwater Benthic Ecosystems. San Diego, California: Academic Press, p. 333.

Stevenson RJ. 1997. Scale-dependent determinants and consecuences of benthic algal heterogeneity. J North Am Benthol Soc 16: 248-263.

Stevenson RJ., Pan Y, van Dam H. 2010. Assessing environmental conditions rivers and stream with diatoms. In: Smol JP, Stoermer EF, eds. The Diatoms. Applications for the Environmental and Earth Sciences. 2da edn. Cambridge, UK: Cambridge University Press, pp. 57-85.

ter Braak CJF, Smilauer P. 1998. CANOCO Reference Manual and User's Guide to Canoco for Windows: Software for Canonical Community Ordination (version 4). Microcomputer Power, Ithaca, New York, USA, p. 352.

Tornés E, Cambra J, Gomá J, Leira M, Ortiz R, Sabater S. 2007. Indicator taxa of benthic diatom communities: a case study in Mediterranean streams. Ann Limnol - Int J Lim 43: 1-11.

Vyverman W, Verleyen E, Sabbe K, Vanhoutte K, Sterken M, Hodgson D, Mann DG, Juggins S, Van De Vijver B, Jones V, Flower R, Roberts D, Chepurnov V, Kilroy C, Vanormelingen P, de Wever A. 2007. Historical processes constrain patterns in global diatom diversity. Ecology 88: 1924-1931.

Wellnitz T, Rader R. 2003. Mechanisms influencing community composition and succession in mountain stream periphyton: 
interactions between scouring history, grazing, and irradiance. $J$ North Am Benthol Soc 22: 528-544.

Wetzel R, Likens G. 2000. Limnological Analyses. 3rd edn. Springer, EEUU, p. 429.
Zapata A, Donato J. 2005. Cambios diarios de las algas perifiticas y su relación con la velocidad de corriente en un río tropical de montaña (río Tota - Colombia). Limnetica 24: $327-$ 338.

Cite this article as: Donato-R, JC, Abuhatab-A,YA. Factors driving diversity and succession of diatom assemblages in a Neotropical rainforest stream. Ann. Limnol. - Int. J. Lim. 54:30 